\title{
SPATIAL DISTRIBUTION OF THE FAUNA OF THE SOIL ON THE LONG-TERM SYSTEM OF DIRECT SOWING
}

\author{
Jessica Zuanazzi Fioritti Corbo ${ }^{1}$; Glécio Machado Siqueira ${ }^{2,}$; Sidney Rosa Vieira ${ }^{1}$; Raimunda Alves \\ Silva ${ }^{2}$
}

${ }^{2}$ Agronomic Institute, IAC - Campinas/SP, Brazil. ${ }^{2}$ Federal University of Maranhão, UFMA - Geosciences Department. São Luís/MA, Brazil.

*Corresponding author: jezuanazzi@outlook.com

Received: Jan. 07, 2017 - Accepted: Aug. 12, 2017

http://dx.doi.org/10.22615/2526-1746-jgm-2.2-6890

\begin{abstract}
The soil is a complex system constituted of living beings, minerals and organic particles, whose components define their physical, chemical and biological properties. The fauna of the soil has an important role in the soil and its diversity can reflect and interfere with the functioning of the soil. The population of these organisms can be influenced by management practices, fertilizing, liming, porosity, and others. Such changes may reduce the composition and the distribution of soil fauna community. Thus, the aim of this work was to determine the spatial variability of the soil fauna in the consolidated direct sowing. The experimental area is located in the CEC (Experimental center of the central Agronomy Institute) in Campinas, São Paulo. The sampling was carried out in Eutroferric Red Latosol, with direct sowing. In the area were sampled 302 points distributed in a 3.2-hectare area on a regular grid of $10 \mathrm{~m} \times 10 \mathrm{~m}$. The fauna was sampled by pitfall traps method and the traps remained in the area for a seven days period. The data were analyzed through descriptive statistics for determining the main statistical moments (average, variance, the coefficient of variation, standard deviation, skewness, and kurtosis). Geostatistics tools were used to determine the spatial variability of the attributes in studies using the experimental semivariogram. In the biodiversity analysis, was calculated Shannon index for each sample, the richness and the number of individuals. The geostatistical demonstrated to be a great tool for the mapping of spatial variability of the epigeal group fauna of the soil. The Family Formicidae has demonstrated to be the most abundant and dominant group in the study area. The parameters of descriptive statistics have demonstrated that all the attributes in the study presented lognormal frequency distribution for the epigeal group fauna of the soil. The exponential model was that which best adjusted to the data in the study, both for the epigeal group fauna of the soil groups (Acari, Araneae, Coleoptera, Formicidae and Larva of Coleoptera), as for the biological diversity index (Shannon Index and Pielou Index). The sampling scheme (10,00 $\mathrm{m} \times 10,00 \mathrm{~m})$ was not enough to detect the spatial variability for all groups of epigeal group fauna of the soil found in this study.
\end{abstract}

Key words: fauna of the soil, diversity, biodiversity indicators, management systems, geostatistics.

\section{DISTRIBUIÇÃO ESPACIAL DA FAUNA DO SOLO NO SISTEMA DE SEMEADURA DIRETA DE LONGA DURAÇÃO}

RESUMO: O solo é um sistema complexo constituído de seres vivos, partículas minerais e orgânicas, cujos componentes definem suas propriedades físicas, químicas e biológicas A fauna do solo tem importante papel no solo e a sua diversidade pode refletir e interferir no funcionamento do solo. A população desses organismos pode ser influenciada por práticas de manejo, adubação, calagem, porosidade, entre outros. Tais alterações podem diminuir a composição e a distribuição da comunidade da fauna do solo. Desta maneira, o objetivo deste trabalho foi determinar a variabilidade espacial da fauna do solo no sistema de semeadura direta consolidado. A área experimental está localizada no CEC (Centro Experimental Central do Instituto Agronômico) em Campinas, São Paulo. As amostragens foram realizadas em Latossolo Vermelho Eutroferrico, com semeadura direta. Na área foram amostrados 302 pontos distribuídos em uma área 3,2 hectare numa malha regular de $10 \mathrm{~m} \times 10 \mathrm{~m}$. A fauna foi amostrada pelo método pitfall traps e as armadilhas permaneceram na área por um período de sete dias. Os dados foram analisados por meio de estatística descritiva para determinação dos principais momentos estatísticos (média variância, coeficiente de variação, desvio padrão, assimetria e curtose). Ferramentas de geoestatística foram utilizadas para se determinar a variabilidade espacial dos atributos em 
estudos utilizando o semivariograma experimental. Na análise da biodiversidade foi calculado o índice de Shannon para cada amostra, a riqueza e o número de indivíduos. A geoestatística demonstrou ser uma ótima ferramenta para o mapeamento da variabilidade espacial dos grupos da fauna epígea do solo. A Família Formicidae demonstrou ser o grupo mais abundante e dominante na área de estudo. Os parâmetros da estatística descritiva demonstraram que todos os atributos em estudo apresentaram distribuição de freqüência lognormal para os grupos da fauna epígea do solo. O modelo exponencial foi o que mais se ajustou aos dados em estudo, tanto para os grupos da fauna epígea do solo (Acari, Araneae, Coleoptera, Formicidae e Larva de Coleoptera), quanto para os índices de diversidade biológica (Índice de Shannon e Índice de Pielou). O esquema de amostragem (10,00 m x 10,00 m) não foi suficiente para detectar a variabilidade espacial para todos os grupos da fauna epígea do solo encontrados neste estudo.

Palavras-chave: fauna do solo, diversidade, indicadores de biodiversidade, sistemas de manejo, geoestatística.

\section{INTRODUCTION}

The soil is a complex system constituted of living beings, minerals and organic particles, whose components define their physical, chemical and biological properties (OLIVEIRA, 2008).

The soil fauna is invertebrate animals that present wide variety of size and are responsible for numerous soil functions (AQUINO, 2001). It can be classified according to their size, mobility, eating habits and of the duties that they perform in the soil (CORREIA et al., 2000).

The microfauna of the soil, whose body diameter is $4 \mathrm{~m}$ to $100 \mathrm{~m}$ acts directly and indirectly in nutrient cycling through ingestion of bacteria and fungi (SWIFT et al. 1979).

The soil mesofauna is the organisms, which are between $100 \mathrm{~m}$ and $2 \mathrm{~mm}$ of body diameter, represented by mites and collembolas, being quite abundant in the soil and for do not pass $3 \mathrm{~mm}$ in length serve as food for edaphic arthropods (SWIFT et al. 1979).

The macrofauna components present body diameter between $2 \mathrm{~mm}$ and $20 \mathrm{~mm}$, represented by termites (Isoptera), beetles (Coleoptera), cicadas and leafhoppers (Auchenorryncha), leafhopper and cricket
(Orthoptera), spiders (Arachnida), woodlice (Isopoda), lice -snake (Diplopoda), mollusks (Mollusca), worms (Oligochaeta), ants (Hymenoptera), thumbtack (Heteroptera), thrips (Thysanoptera), butterflies and moths (Lepidoptera), flies and mosquitoes (Diptera), cockroaches (Blattodea), among others. They are responsible for homogenizing the soil and carry the opening galleries, theirs excretes modify their pore spaces (PRIMAVESI, 1999), increasing the penetration of roots and the internal flow of air and water (OLIVEIRA, 2008).

The meso and macrofauna mainly develop detritivorous and predatory functions. These functions can be associated with several processes such as nutrient cycling, soil revolving, incorporation of organic matter and biological control of soil pests (MELO et al., 2009).

These organisms ingest a complex mixture of organic materials contributing to the state of soil aggregation, the excreta left in the land begin to become part of the aggregate structure serving to increase the water retention capacity, the aeration and the drainage, facilitating the penetration the roots and avoiding erosion (CORREIA, 2002).

According to RODRIGUES (2010), the soil fauna organisms contribute significantly to 
the evaluation of the soil quality and its functionality, as are intimately associated with the process of decomposition and nutrient cycling. Representing an important tool to assess soil recovery processes in degraded areas. The main characteristic of a good indicator is to be sensitive to change in land use, responding quickly the arising effects of the management changes (MERLIM, 2005).

The preparation of the soil, itself, as fertilizing, liming, compaction, osmotic pressure, porosity, available nutrients, minerals, among others, may interfere in the diversity of soil fauna (BARETTA, 2007; CIVIDANTES et al., 2009).

The tillage system was introduced in Brazil in the early 1970s in the South Region. Today in Brazil, the agricultural area under Tillage system is approximately twenty-five million hectares, half of the cultivated area with the country's grain (DECHEN, 2007).

This conservationist soil management system seeks to be a sustainable agricultural production, in which does not occur to the soil movement (SIQUEIRA, 2006). Its initial aim was to control hydric erosion that has only become possible with the help of many collaborators (OLIVEIRA et al., 2002).

It is characterized by the maintenance of straw left by the preceding harvest, reducing the rate of mineralization of organic matter, favoring of the biological activity in the control of pests and weeds and by an intensification of soil aggregation processes (SEIXAS, 2001).

The sowing is made with appropriate machines that open furrows on the lines of planting, in which the seeds are deposited (AQUINO et al., 2008), GODOY et al. (2007), observed that the direct sowing system, when compared with the conventional tillage system, provides a higher density of saprophytic, geophagic and predators organisms of edaphic community, which can promote the control of several agricultural pests, and reduce the use of insecticides.

The spatial variability of soil organisms is still understudied and there are few works talking about it. In addition, the knowledge of the spatial variability of biological properties may indicate better alternatives for a sustainable soil management (RODRIGUES, 2010).

The spatial variability of soil attributes is related to different factors such as: climate, relief, organisms' action, time, a variation of the source material, management techniques and soil genetic processes. Statistical methods such as: semivariogram, kriging has been used to study the spatial variability of soil attributes, taking into account the understanding of the processes of soilorganism interaction (SCHAFFRATH et al., 2007). VIEIRA (2000) has demonstrated that in nearest locations amongst themselves are more similar than those that are further away.

In this sense, it is worth highlighting the importance of the monitoring the diversity of the soil fauna groups as well as their spatial variability that enables the knowledge of its dynamics and allows the development of biodiversity indicators and the use of the soil considering its ecological function.

This study aimed to determine the diversity and spatial variability of soil fauna in the consolidated direct sowing system in Campinas, São Paulo State (Brazil). 


\section{MATERIAL AND METHODS}

The survey of soil fauna was conducted at the Experimental Center of the Agronomic Institute (IAC), Campinas, São Paulo (Brazil). Its location is between the coordinates: latitude $22^{\circ} 53^{\prime}$ South, longitude $47^{\circ} 04^{\prime}$ 'West, with an average altitude of $600 \mathrm{~m}$ and declivity of $6.5 \%$.
According to the international climate classification of Köppen, the region of Campinas presents transition between climatic types Cwa and Cfa, in other words, tropical climate of altitude with dry winter and wet summer. With an average annual precipitation of $1,382 \mathrm{~mm}$ (ORTOLANI et al., 1995).

Table 1. Main physical (clay, silt, total sand, coarse sand and fine sand) and chemical (OM) characteristics of the soil from the study area located in Campinas- São Paulo (Brazil). (SIQUEIRA, 2006).

\begin{tabular}{ccccccccc}
\hline Horizon & & \multicolumn{5}{c}{ Granulometric composition $(\mathrm{g} \mathrm{kg}-1)$} & OM \\
\hline Symbol & Depth $(\mathrm{cm})$ & Clay & Silt & Total sand & Coarse sand & Fine sand & $(\mathrm{g} \mathrm{kg}-1)$ \\
\hline Ap1 & $0-12$ & 588 & 160 & 253 & 148 & 105 & 33,0 \\
Ap2 & $12-32$ & 563 & 217 & 221 & 125 & 96 & 28,0 \\
BA & $32-58$ & 663 & 130 & 207 & 115 & 92 & 18,0 \\
Bw1 & $58-92$ & 663 & 139 & 198 & 105 & 93 & 18,0 \\
Bw2 & $92-140$ & 663 & 132 & 205 & 108 & 98 & 13,0 \\
Bw3 & $140-200$ & 663 & 128 & 209 & 113 & 96 & 6,0 \\
Bore. 1(1) & $200-250$ & 688 & 112 & 200 & 107 & 93 & 6,0 \\
Bore. 2(1) & $250-300$ & 688 & 109 & 204 & 111 & 93 & 10,0 \\
\hline
\end{tabular}

$\left({ }^{1}\right)$ Borehole.

The study was conducted in the area of a long-term experiment installed since 1985, in 3.42 hectares, under the direct sowing system. The area was maintained without any cultivation from 1975 to 1985. In March 1985, the field was cleared, plowed and cultivated with Crotalaria juncea L. and, in November of the same year, the field was subsoiler, limed, plow, meshed and cultivated with soybeans. Since then, the adopted system is the direct sowing with soybeans [Glicine max (L.) Merrill] and maize (Zea mays L.) in alternate years in the summer and black oat (Avena strigosa Schieb.), rye (Cecale cereale L.), triticale (Triticale secale L.), wheat (Triticum aestivum L.) or Crotalaria juncea L. as winter cultures (SIQUEIRA, 2006).

The soil of the area is a Eutroferric Red Latosol, with a clayey texture (EMBRAPA, 2006), whose main chemical and physical characteristics are shown in Table 1.

The slope of the area is about $6.5 \%$ with an average altitude of $650 \mathrm{~m}$. The study area was divided into a regular grid of $10 \mathrm{~m} \times 10 \mathrm{~m}$, totalizing 302 sampling points, where was sampled the epigeal fauna of the soil (Figure $1)$. 


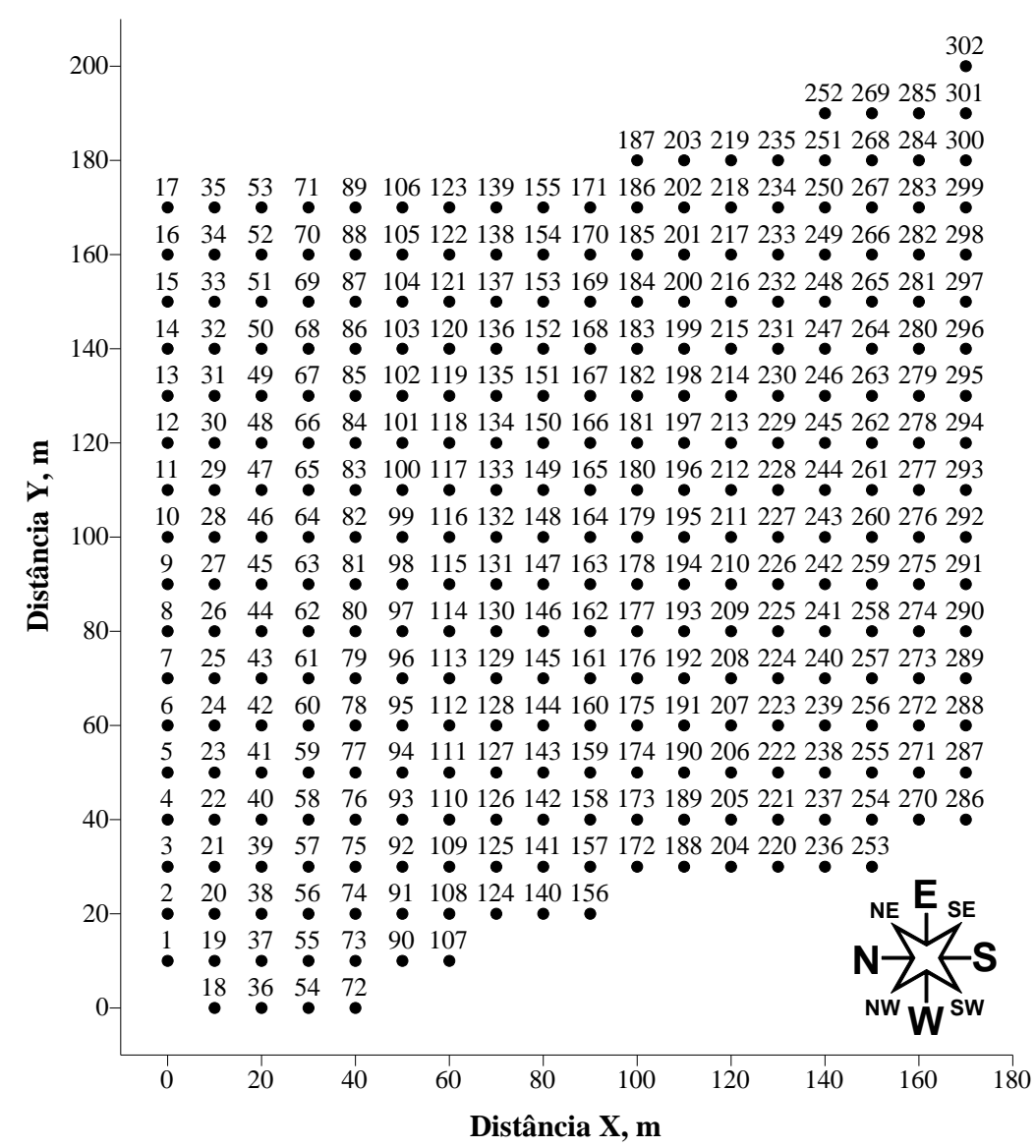

Figure 1. The sampling collect grill of the soil fauna in the area with long-term direct sowing located in the Farm Santa Elisa, Agronomic Institute of Campinas, containing the 302 sampling points with regular spacing of $10 \times 10$ meters.
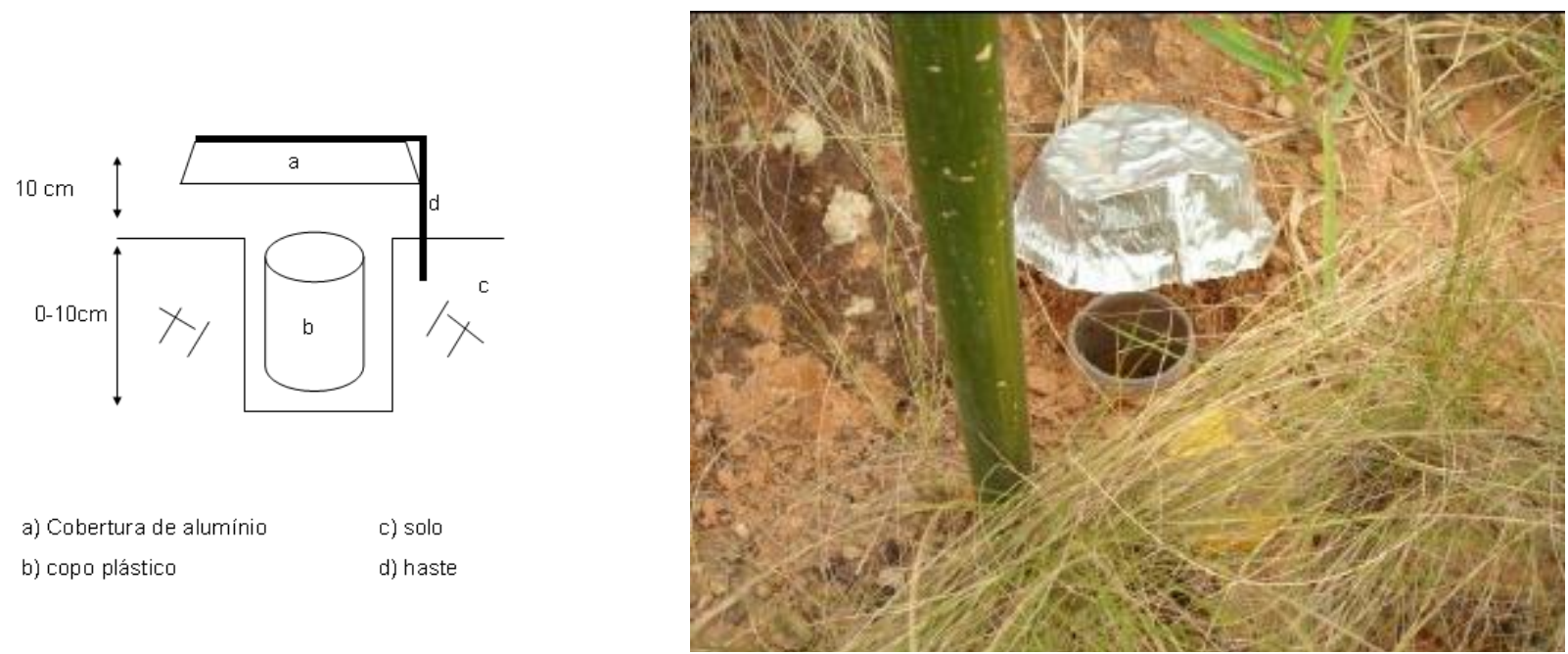

Figure 2. Schematic drawing of the trap (a); Pitfall trap for capture of the soil in direct sowing system (b).

The collection of epigeal soil fauna occurred in August 2010, coinciding with the tillage and winter harvest, with the cultivation of triticale (Triticum secale).
For the extraction of the individuals were used pitfall traps (BELT and OLIVEIRA, 2000), which consists of a plastic container with approximately $9 \mathrm{~cm}$ in height and $8 \mathrm{~cm}$ in diameter which stays at ground level (Figures 
3 and 4). The surface animals accidentally fall into the trap as they move. To minimize the damage caused by the rain or by the flow on the soil surface, a plastic cover was adapted.

Each trap remained in the field for a period of seven days, containing inside it $200 \mathrm{ml}$ of formaldehyde at $4 \%$ so that the animals would not escape and were conserved, according to the procedures described by AQUINO (2001). At the end of seven days period, the traps were removed from the field and the content was stored in vessels containing $70 \%$ of alcohol, for the conservation of the material during the identification and counting period. The vessels were identified with the number of each point, sampling area name, and date of collection. Next, the components of soil fauna were removed manually with tweezers aid. The contents of each collecting vessel were transferred, in the laboratory, for a petri dish, for identification, with the aid of a stereomicroscope, counted and separated into groups, order or family, if necessary. After identifying the number of individuals, the same were stored again in the collecting vessels and separated into groups, functionals according to SCIRO (1991); DINDAL (1990); GALLO et al.,(1988).

In data analysis, was initially determined the total of individuals captured of each order or group. As the trap remained in the camp during for seven days, the values were divided by seven, presenting results of individuals per trap per day.

The richness is the measure that evaluates the number of species found in an area, and, in our case, was the number of groups or orders found, since the wildlife identification was carried out in the level of large taxonomic groups.
Subsequently were determined the biodiversity index and the spatial variability of soil fauna.

The diversity index was used to quantify the area diversity, taking into account the number of present groups and the relative abundance, for which used the ShannonWiener index. The Pielou index is a variation of Shannon index for the richness and values close to 1 indicate that the relative abundance of the groups is similar and values close to 0 indicate the dominance of some group.

To verify the spatial variability of the variables, the results were analyzed through geostatistical methods of semivariograms analysis, described by VIEIRA (2000), starting from the presupposition of stationarity of the intrinsic hypothesis. The spatial autocorrelation among neighbors sites was calculated by the semivariance $r(h)$.

According to VIEIRA (2000), is expected measurements closely located be more alike each other than those separated by large distances. In this way, it is expected to increase $r(h)$ the distance $h$ to a maximum value at which stabilizes at a correspondent level to the limit distance of spatial dependence, which is the range. Measurements located at distances greater than the range, have random distribution and, therefore, are independent of each other, for which the classical statistics can be applied.

Mathematical models were adjusted to semivariograms, which allow viewing the nature of the spatial variation of the variables. The criteria and procedures for semivariogram model adjustment are according to VIEIRA et al. (1983). Of the adjustment of a mathematical model to the data, semivariogram parameters were 
defined: a) nugget effect $\left(C_{0}\right)$, which is a $r$ value when $\mathrm{h}=0$; $\mathrm{b}$ ) spatial dependence range (a), which is the distance whereby $r(h)$ remains approximately constant, after increasing with the increase of $h$; c) level $\left(C_{0}+C_{1}\right)$ which is the value of $r(h)$ from the range and that gets closely from the data variance, if exists.

It was established the spatial dependence degree, which is the proportion of the nugget effect in relation to the level, and that, according to CAMBARDELLA et al. (1994) presents the following proportion: a) Strong for $\mathrm{C}_{0}<25 \%$ of $\left(\mathrm{C}_{0}+\mathrm{C}_{1}\right)$; b) moderate for $\mathrm{C}_{0}=$ $25-75 \%$ of $\left(C_{0}+C_{1}\right)$; and $\left.c\right)$ weak for $C_{0}>75 \%$ of $\left(C_{0}+C_{1}\right)$. Was still used, the semivariogram scheduling, as a way of grouping the data to facilitate the interpretation, adopting, as scheduling factors, the variance of the data or the level of the adjusted model.

The result of the work was expressed in the form of spatial variability map and the manner of locate an isoline between two points will be by kriging interpolation, which according to VIEIRA et al. (1991), guarantees that the construction of the maps be the best possible, because the estimates are made without trend and with minimum variance. The surfer software will be used for manipulation and visualization of the spatial distribution, through the construction of isolines map of the variables due to the geographic coordinates, in order to verify if variations happen between the sampling days, along the study period.

\section{RESULTS AND DISCUSSION}

Table 2 presents the main statistical moments for epigeal soil fauna for Eutroferric
Red Latosol in Campinas (São Paulo State, Brazil) under long-term direct sowing. The Formicidae family was the most frequent in the study area, occurring in 300 of the $\mathbf{3 0 2}$ sampling points, followed subsequently by the orders Acari (286), Coleoptera larvae (269), Coleoptera (192), Araneae (191), Entomobryomorpha (191), Orthoptera (62), Heteroptera (46), Diptera (32), Isoptera (32), Hymenoptera (26), Blattodea (22), Auchenorryncha (21), Diplopoda (20), Thysanoptera (12), Diplura (6), Hirudinea (6) and Enchytraeidae (4).

The variation coefficient values (CV, \%) according to the classification of WARRICK and Nielsen (1980) are classified as: CV $\leq 12$ $\%$, low; CV 12,00-60,00 \% mediums; CV $\geq 60$ $\%$, high. For this study, the following attributes presented high values of CV: Acari $(94,20 \%)$, Araneae $(119,10 \%)$, Coleoptera (140,95 \%), Diptera (91,29 \%), Entomobryomorpha (96,28\%), Formicidae $(60,16 \%)$, Heteroptera (122,23\%), Isoptera $(139,91 \%)$ and Coleoptera larvae (122,18 \%). The other attributes had presented median coefficients of variation. RODRIGUES (2010) studying the epigeal soil fauna found the higher coefficient of variation values, however, this difference is due to the number of sample points. In this study, were employed 302 sampling points with a spacing of $10 \mathrm{~m} \times 10 \mathrm{~m}$ (3.42 ha), while in the study of ROBERTS (2010) were sampled 92 points with a spacing of $5 \mathrm{~m} \times 5 \mathrm{~m}$ (0.22 ha).

Regarding the nature of the data, were already expected high values of the coefficient of variation (CV\%). According to WARRICK and NIELSEN (1980) the CV values for soil attributes can reach up to $1000 \%$ according to their nature. In the case of epigeal soil fauna, its distribution across the 
landscape is conditioned by several factors, such as: climate, soil, quality and amount of vegetable resource, human activity and type of management (LAVELLE, 1996).

The Formicidae family presented the higher variance value (865.36), indicating that the presence of these animals in the traps varied considerably between the sampling points. Other groups also presented high variance values (Acari: 331.08; Coleoptera larvae: 157.22). ETTEMA and WARDLE (2002) describe that these differences are normal because the spatial aggregation is influenced by population intrinsic processes such as: reproduction, dispersion, and competition. On the other hand, it should also be considered the dominance between the species, as reported by TOLEDO (2003).

Table 2. Statistical parameters for epigeal soil faunal groups present in the Eutroferric Red Latosol under long-term direct sowing in Campinas (SP).

\begin{tabular}{|c|c|c|c|c|c|c|c|}
\hline & $\mathrm{N}$ & Average & Median & CV (\%) & Variance & Skewness & Kurtosis \\
\hline Acari & 286 & 19.31 & 14.00 & 94.20 & 331.08 & 2.55 & 9.59 \\
\hline Araneae & 191 & 2.30 & 2.00 & 119.10 & 7.49 & 7.84 & 83.70 \\
\hline Auchenorryncha & 21 & 1.24 & 1.00 & 44.53 & 0.29 & 2.32 & 5.06 \\
\hline Blattodea & 22 & 1.09 & 1.00 & 27.97 & 0.09 & 3.06 & 8.09 \\
\hline Coleoptera & 192 & 2.05 & 1.00 & 140.95 & 8.17 & 9.19 & 98.66 \\
\hline Diplopoda & 20 & 1.20 & 1.00 & 44.59 & 0.27 & 2.75 & 7.40 \\
\hline Diplura & 6 & 1.33 & 1.00 & 39.73 & 0.27 & 0.97 & -1.88 \\
\hline Diptera & 32 & 1.81 & 1.00 & 91.29 & 2.74 & 3.10 & 11.36 \\
\hline Enchytraeidae & 4 & 1.25 & 1.00 & 40.00 & 0.25 & 2.00 & 4.00 \\
\hline Entomobryomorpha & 191 & 8.14 & 7.00 & 96.28 & 61.45 & 3.39 & 18.89 \\
\hline Formicidae & 300 & 48.89 & 42.00 & 60.16 & 865.36 & 1.43 & 3.26 \\
\hline Heteroptera & 46 & 1.85 & 1.00 & 122.23 & 5.11 & 4.14 & 19.55 \\
\hline Hirudinea & 6 & 1.17 & 1.00 & 35.99 & 0.17 & 2.45 & 6.00 \\
\hline Hymenoptera & 26 & 1.08 & 1.00 & 25.23 & 0.07 & 3.37 & 10.16 \\
\hline Isoptera & 32 & 2.25 & 1.00 & 139.91 & 9.81 & 2.85 & 6.92 \\
\hline Coleoptera Larvae & 269 & 10.29 & 6.00 & 122.18 & 157.22 & 3.41 & 15.52 \\
\hline Orthoptera & 62 & 1.24 & 1.00 & 43.96 & 0.28 & 2.18 & 3.94 \\
\hline Thysanoptera & 12 & 1.08 & 1.00 & 27.64 & 0.08 & 3.46 & 12.00 \\
\hline
\end{tabular}

$\mathrm{N}$ : frequency number; CV: coefficient of variation.

Table 3. Statistical parameters for the biological diversity indexes in Eutroferric Red Latosol under long-term direct sowing in Campinas (SP).

\begin{tabular}{lccccccc}
\hline & N & Average & Median & CV (\%) & Variance & Skewness & Kurtosis \\
\hline Shannon index & 300 & 1.554 & 1.560 & 23.58 & 0.134 & -0.402 & 0.936 \\
Pielou index & 302 & 0.635 & 0.650 & 19.99 & 0.016 & -0.485 & 1.215 \\
Average richness & 302 & 6.000 & 6.000 & 27.10 & 2.422 & 0.149 & -0.213 \\
\hline
\end{tabular}

$\mathrm{N}$ : frequency number; CV: coefficient of variation.

The skewness and kurtosis values for the groups of epigeal soil fauna in the study, demonstrate that all attributes had presented lognormal distribution frequency, following the criteria for CARVALHO et al. (2003) that related that the skewness and kurtosis values should be close to 0 and 3, respectively. The analysis of the average and median data demonstrated that there is no similarity 
between their values, corroborating for the data non-normality.

The biological diversity indicators (Table 3) presented a median coefficient of variation values (CV\%). RODRIGUES (2010) studying the epigeal soil fauna also found median CV values for the biological diversity indicators (Shanon index, Pielou index, and Richness Average).

The average value of biological diversity of Shannon index is above of 1.00 indicating that the diversity of the _ epigeal soil fauna in the study area is high, as described by MAGURRAN (1989) and JACOBS et al. (2007). The Shannon Index measures the degree of uncertainty in predicting to which species will belong a chosen individual, randomly, from a sample of $\mathrm{S}$ species and $\mathrm{N}$ individuals. The smaller the value of Shannon index, the lower the uncertainty degree and, therefore the diversity of the sample is low (MAGURRAN, 1989; KREBS, 1999; URAMOTO et al., 2005; JACOBS et al., 2007).

TISSARO (2009) in a study of maize cultivated with direct sowing and different dosages of chemical fertilizer, found values of Shannon index around 0.9, these values lower than those found in this study (Table 3). ALVES et al. (2006) studying the epigeal soil fauna in Campinas (SP) on the direct sowing system and the conventional system found biological diversity Shannon values around 1.57 for the direct sowing system and 1.21 for a conventional system. ALMEIDA et al. (2007) studying the soil fauna in direct sowing system influenced by liming, describe an average of 1.23 for the Shannon Index on the direct sowing system.

The equitability index of Pielou presented an average value of 0.635 demonstrating that the study area all species are equally abundant, describing this way the uniformity of individuals distribution among the existing species. According to CORREIA et al. (2006), the Pielou index presents a range from 0 (minimum uniformity) to 1 (maximum uniformity). ALMEIDA et al. (2007) found values of Pielou Index in direct sowing system of around 1.45. ALVES et al. (2006) found a value of Pielou index of 1.64. Was verified that the values found in this study are lower than those previously found by the described authors.

The average Richness in this study by trap was of 6 individuals. ALMEIDA et al. (2007) found a richness of 12 individuals per trap being the samplings carried out in December 2005, during the summer season that favors the development of the epigeal soil fauna (CORREIA et al., 2006). Furthermore, ALVES et al. (2006) studying the richness of the soil fauna in Campinas found values close to the average richness of the epigeal soil fauna sampled in the winter (11) and summer (10) in the direct sowing system.

Regarding the asymmetry and kurtosis data for the biological diversity of soil parameters under direct sowing in Campinas, as previously described by the classification of CARVALHO et al. (2003) the data presented lognormal frequency distribution.

According to ISAAKS and SRIVASTAVA (1989) the normality of the data is not an impediment to the use of geostatistics. Once that the most important than the data normality is that the same do not present trend, satisfying in this way the intrinsic hypothesis of geostatistics in relation to the stationarity, where all the data belong to the same population, or ranging around the average (SIQUEIRA, 2006). 
According to ISAAKS and SRIVASTAVA (1989) the normality of the data is not an impediment to the use of geostatistics. Once that the most important than the data normality is that the same do not present trend, satisfying in this way the intrinsic hypothesis of geostatistics in relation to the stationarity, where all the data belong to the same population or ranging from the average. The presence of pure nugget effect indicates that the sampling was not enough to detect the spatial variability of these groups. We emphasize that many of these groups present aggregate behavior in the field, which explains the presence of pure nugget effect, indicating that to detect the spatial variability of these groups the spacing between the sampling points should be reduced.

Table 4. Semivariogram parameters for epigeal soil fauna groups present in the Eutroferric Red Latosol under long-term direct sowing in Campinas (SP).

\begin{tabular}{|c|c|c|c|c|c|}
\hline & Model & $\mathrm{C}_{0}$ & $\mathrm{C}_{0}+\mathrm{C}_{1}$ & A & GD \\
\hline Acari & Exponential & 32.60 & 341.70 & 34.50 & 9.54 \\
\hline Araneae & Exponential & 1.96 & 8.74 & 10.30 & 22.42 \\
\hline Auchenorryncha & & & Pure nugget effect & & \\
\hline Blattodea & & & Pure nugget effect & & \\
\hline Coleoptera & Exponential & 2.87 & 10.26 & 16.00 & 27.97 \\
\hline Diplopoda & & & Pure nugget effect & & \\
\hline Diplura & & & Pure nugget effect & & \\
\hline Diptera & & & Pure nugget effect & & \\
\hline Enchytraeidae & & & Pure nugget effect & & \\
\hline Entomobryomorpha & & & Pure nugget effect & & \\
\hline Formicidae & Exponential & 35.00 & 849.20 & 27.00 & 4.12 \\
\hline Heteroptera & & & Pure nugget effect & & \\
\hline Hirudinea & & & Pure nugget effect & & \\
\hline Hymenoptera & & & Pure nugget effect & & \\
\hline Isoptera & Gaussian & 3.47 & 19.67 & 89.00 & 17.64 \\
\hline Larva Coleoptera & Exponential & 0.10 & 132.40 & 36.40 & 0.07 \\
\hline Orthoptera & & & Pure nugget effect & & \\
\hline Thysanoptera & & & Pure nugget effect & & \\
\hline
\end{tabular}

$\mathrm{C}_{0}$ : nugget effect; $\mathrm{C}_{0}+\mathrm{C}_{1}$ : level; a: range $(\mathrm{m})$; DD: degree of spatial dependence $[(\mathrm{CO} / \mathrm{CO}+\mathrm{C} 1) 100]$.

The Gaussian model was adjusted by the Isoptera group, while the other groups presented spatial dependence through the semivariogram were adjusted to the exponential model (Acari, Araneae, Coleoptera, Formicidae and Coleoptera larvae). According to CAMBARDELLA et al. (1994), VIEIRA (2000) and SMITH (2006), the spherical model is most common for the soil properties. In this sense, we observed that the data nature itself in the study favors a greater dispersion and environmental interaction, unlike other physical and chemical soil parameters that vary over the landscape.

The greatest value of nugget effect $\left(C_{0}\right)$ was found for the family Formicidae and the lower nugget effect was described for the Coleoptera larvae. According to SMITH (2006), the nugget effect values can be used as an indicator of the accuracy of an experiment. In this sense, it is noted that the presence of low nugget effect values confirms that the spacing used between samples was 
efficient to detect the spatial variability of these same groups in small scale.

The range values $(a, m)$ ranged between $10.30 \mathrm{~m}$ (Aranae) to $89.00 \mathrm{~m}$ (Isoptera). The analysis of range values demonstrates that the spacing between used samples $(10.00 \mathrm{x}$ $10.00 \mathrm{~m}$ ) cannot be increased because it would not guarantee the detection of the spatial variability for all groups were detected spatial dependence with the spacing used in this study.

The degree of spatial dependence among samples $(D D, \%)$ according to the classification of CAMBARDELLA et al. (1994) is low (0.00\% -
25.00\%) for the following groups: Acari, Araneae, Formicidae and Coleoptera larvae, and only the Coleoptera order presented median degree of spatial dependence (25.00\% -75. $00 \%)$.

Regarding the biological diversity indexes of epigeal soil fauna, all the attributes presented spatial dependence through adjusted semivariogram. The Shannon index and Pielou index were adjusted to the exponential model and the average Richness to the Gaussian model

Table 5. Statistical parameters for biological diversity indexes in Eutroferric Red Latosol under long-term direct sowing in Campinas (SP).

\begin{tabular}{lccccc} 
& Model & $\mathrm{C}_{0}$ & $\mathrm{C}_{0}+\mathrm{C}_{1}$ & $\mathrm{a}$ & $\mathrm{DD}$ \\
\hline Shannon index & Exponential & 0.00210 & 0.16120 & 38.00 & 1.20 \\
Pielou index & Exponential & 1.69900 & 3.39900 & 158.00 & 49.98 \\
Average richness & Gaussian & 0.01280 & 0.15260 & 86.20 & 8.28 \\
\hline
\end{tabular}

$\mathrm{C}_{0}$ : nugget effect; $\mathrm{C}_{0}+\mathrm{C}_{1}$ : level; a: range $(\mathrm{m})$; DD: degree of spatial dependence [(CO/CO+C1)100].

The nugget effect values $\left(C_{0}\right)$ for biological diversity indexes of soil fauna to the attributes under study are low. Analyzing the range values $(a, m)$, It is noticed that the biological diversity indexes of soil fauna (Table 5) presented values ranging between $38.00 \mathrm{~m}$ (Shannon Index) and 158.00 m (Pielou Index ). These values are considerably higher than the range values found for the groups of epigeal soil fauna in the study area.

The degree of spatial dependence among the samples (DD\%) for biological diversity indexes of soil fauna are low for the Shannon index (1.20\%) and for the average Richness $(8.28 \%)$, and median the Pielou index (49.98\%).

The spatial variability maps for the groups that presented spatial variability are given in
Figure 3. It is observed that with the exception of the Formicidae group (Figure $3 \mathrm{~d}$ ) all other maps present great homogeneity in the study area. This fact proves the dominance of this class over the other groups, as demonstrated by the frequency number values and average data presented in Table 2. According to RODRIGUES (2010), the spatial distribution of Formidae group is related to the spatial distribution of level of organic carbon.

The maps of Aranae (Figure 3b) and Coleoptera (Figure $3 d$ ) groups have a similar behavior, which is justified by the greater incidence of Aranae order in areas with higher incidence of Coleoptera, due to its predatory characteristic (PODGAISKI et al.; 2007). 
(a) Acari

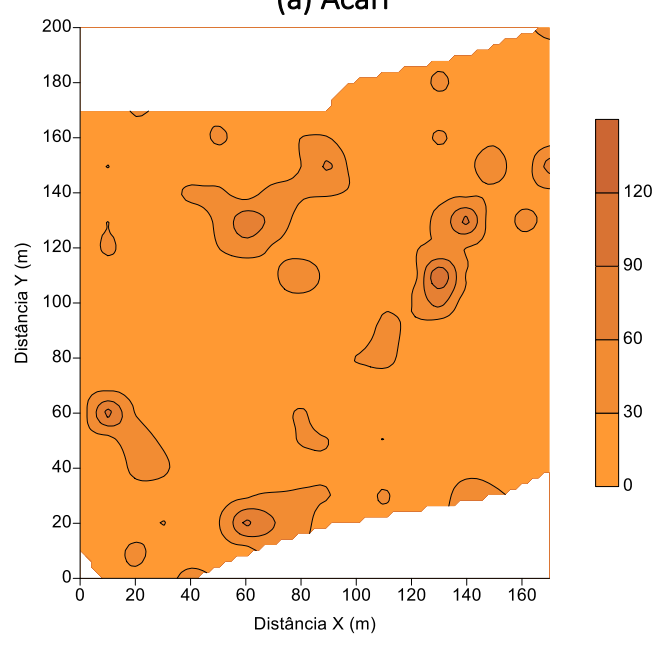

(c) Coleoptera

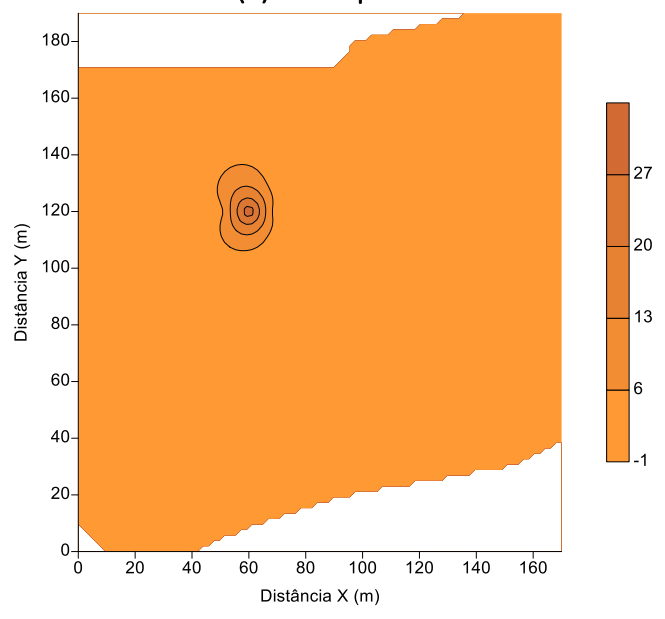

(e) Isoptera

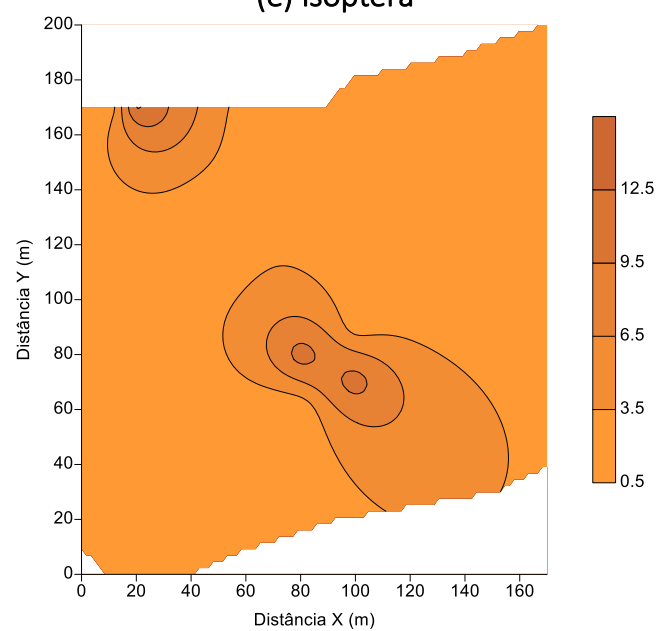

(b) Aranae

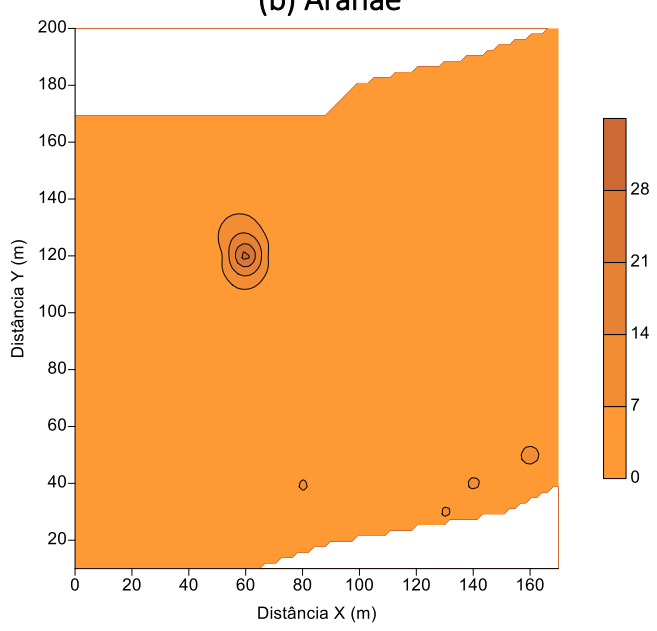

(d) Formicidae
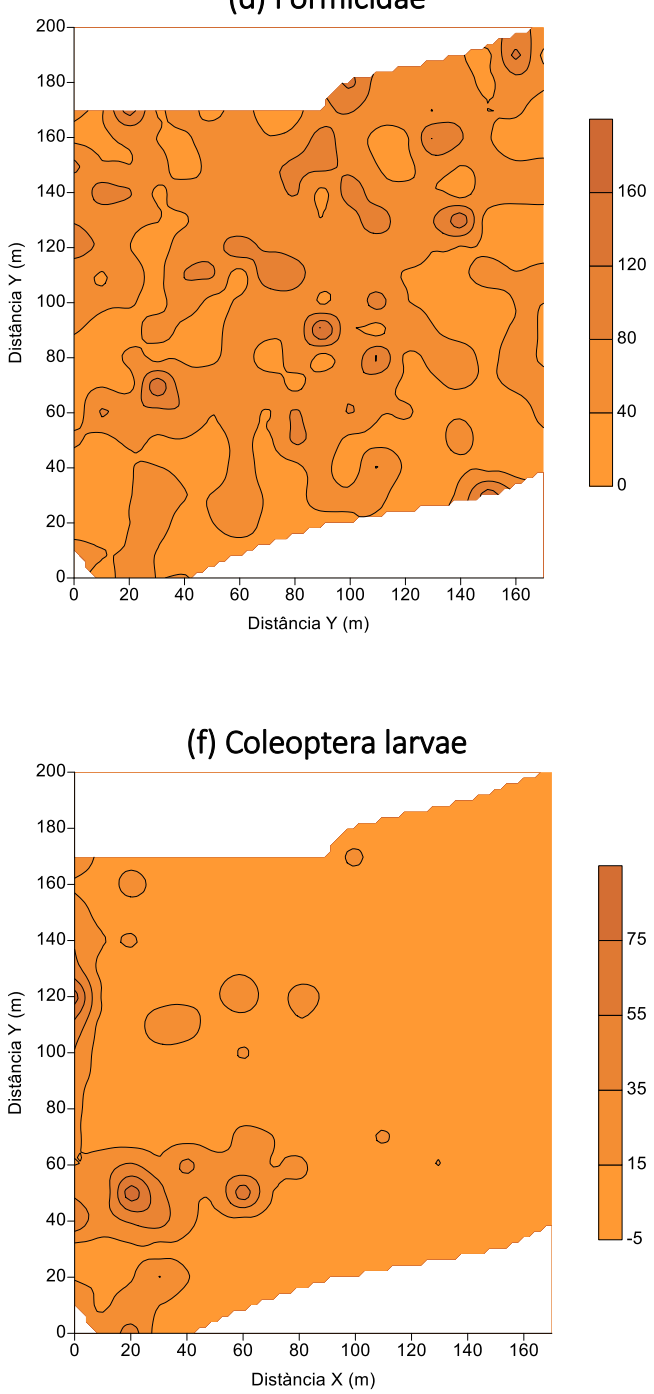

Figure 3. Spatial variability maps for the groups of epigeal soil fauna that presented spatial variability: (a) Acari (b) Aranae, (c) Coleoptera, (d) Formicidae (e) Isoptera and (f) Coleoptera larvae. 
It is noticed also that the Coleoptera larvae (Figure 3f) are mainly located on the left of the area, and having no similarity of spatial distribution with the maps of adult insects (Figure 3c). Regarding the Isoptera order is

(a) Shannon index
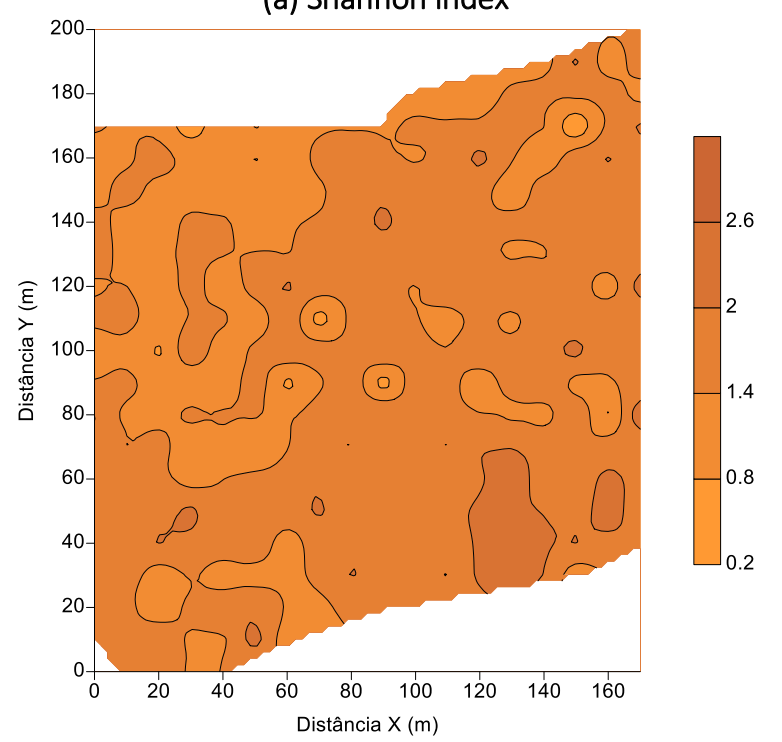

possible to note that there is an aggregate pattern occurring in the study area. According to NUNES et al. (2009), the Isoptera occur in areas with a decrease in organic matter. (b) Pielou index

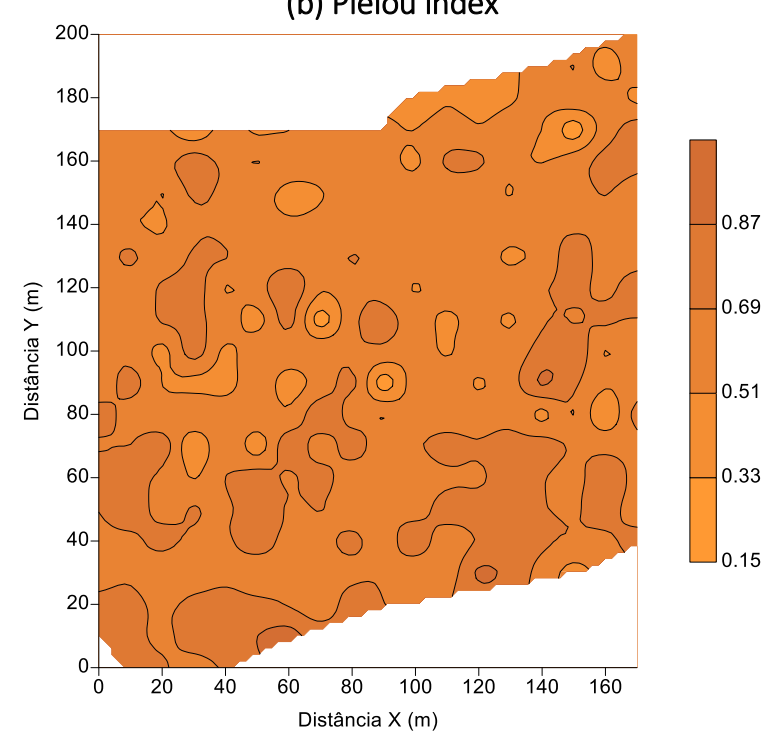

(c) Average richness

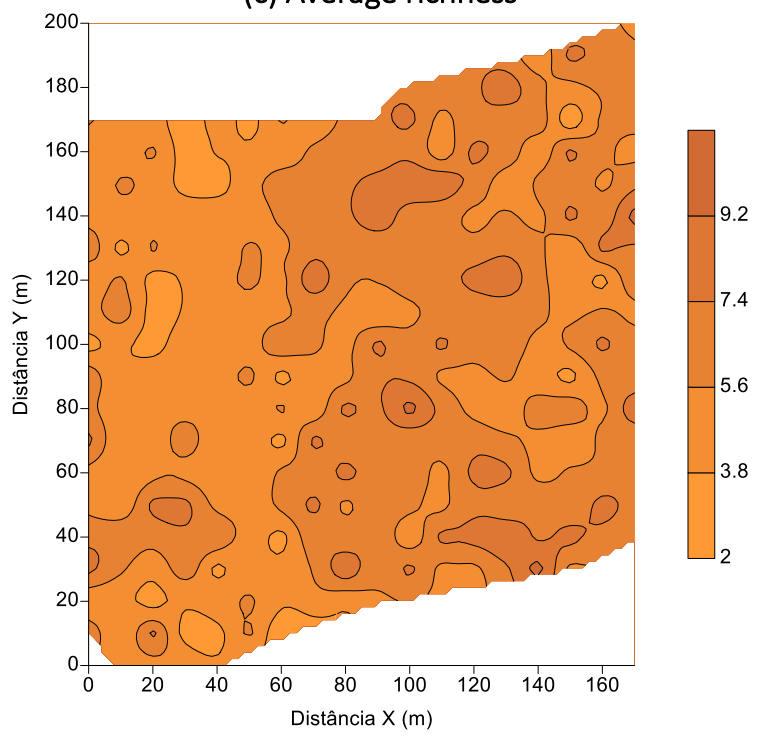

Figure 4. Maps of spatial variability for soil biodiversity indexes: (a) Shannon Index, (b) Pielou Index and (c) Average Richness.

The maps of the variability of soil biological diversity indexes are given in Figure 4. The Shannon Index (Figure 4a) and the Pielou index (Figure 4b) present similar spatial behavior, where we verified that zone with lower values of the Shannon Index coincide with the areas with lower values of Pielou index. This fact reiterates the idea that in the study area there is a wide diversity of groups, but its abundance is reduced.

The map of the Average Richness (Figure 4c) in the study area demonstrates that there 
is a relatively proportional distribution in all study area, once that are few areas with low average richness values. In addition, we proved that the richness map is highly influenced by the spatial distribution and the dominant incidence of family Formicidae.

\section{CONCLUSIONS}

The geostatistical had demonstrated to be a great tool for the mapping of spatial variability of epigeal soil fauna groups. The Formicidae family had demonstrated to be the most abundant and dominant group in the study area. The parameters of descriptive statistics have demonstrated that all the attributes in the study presented lognormal frequency distribution for the epigeal soil fauna groups. The exponential model that best adjusted to the data in the study, such for the epigeal soil fauna groups (Acari, Araneae, Coleoptera, Formicidae and Larva of Coleoptera), as for the biological diversity index (Shannon Index and Pielou Index). The sampling scheme $(10,00 \mathrm{~m} \times 10,00 \mathrm{~m})$ was not enough to detect the spatial variability for all groups of epigeal soil fauna found in this study.

\section{REFEDRENCES}

Almeida, H. C.; Almeida, D.; Alves, M. V.; Mafra, A. L.; Bertol, I. 2007. Propriedades químicas e fauna do solo influenciadas pela calagem em sistema de semeadura direta. Ciência Rural, Santa Maria, v.37, n.5, p. 14621465.

Alves, M. V.; Baretta, D.; Cardoso, E. J. B. N. 2006. Fauna edáfica em diferentes sistemas de cultivo no estado de São Paulo. Ciência Agroveterinárias, Lages, v.5, n.1, p.33-43.

Aquino, A. M. 2001. Manual para coleta de macrofauna do Solo. Seropédica: Embrapa Agrobiologia, 2001. 21p.

Aquino, A. M.; Filho, E. M.; Ricci, M. S.; Casanoves, F. 2008. Populações de Minhocas em sistema agroflorestais com café convencional e orgânico. Ciência Agrotécnica, Lavras, v.32, n.4, p.1184-1188.

Baretta, D. 2007. Fauna do solo e outros atributos edáficos como indicadores da qualidade ambiental em áreas com Araucária angustifólia no estado de São Paulo. 2007. 158p. (Doutorado Agronomia) - Escola Superior de Agricultura Luiz de Queiroz, Piracicaba.

Cambardella, C. A.; Mooman, T. B.; Novak, J. M.; Parkin, T. B.; Karlem, D. L.; Turvo, R. F. \& Konopa, A. E. 1994. Field scale variability of soil properties. In central lowa soil. Soil Science of América Journal, Madison, v.47, p.1501-1511.

CAMBARDELLA, C.A.; MOOMAN, T.B.; NOVAK, J.M.; PARKIN, T.B.; KARLEN, D.L.; TURV, R.F.; KONOPA, A.E. Field scale variability of soil properties in central lowa soil. Soil Science of Society America Journal, v.47, p.1501-1511, 1994.

Carvalho, J. R. P, Silveira, P. M.; Vieira, S. R. 2001. Geoestatística na determinação da variabilidade espacial de características químicas do solo sob diferentes preparos. Pesq. agropec. bras., v.37, n.8, p. 1151-1159.

Cividantes, F. J.; Barbosa, J . C.; Martins, I. C. F.; Pattaro, F.; Nunes, M. A.; Cordeiro, F.C; Dias, F. C; Merlim, A. O; Correia, M. E. F; Aquino, A. M; Brown, G. 2009. Diversidade da Macrofauna do solo como indicadora da qualidade do solo em sistema de manejo orgânico de produção. Revista Universidade Rural. Seropédica, v.24, n.2, p.29-34. 
Correia, M. E. F. 2002. Relações entre Diversidade da Fauna de Solo e o Processo de Decomposição e seus Reflexos sobre a Estabilidade dos Ecossistemas. Seropédica: Embrapa Agrobiologia, 2002. 33p.

Correia, M. E. F.; Oliveira, L. C. M. 2000. Fauna do solo: Aspectos Gerais e Metodológicos. Seropédica: Embrapa Agrobiologia, 2000. 46p.

Dechen, S. C. F. 2007. Sistema plantio direto no Estado de São Paulo. In: Workshop, 206p, 2007, Piracicaba: Fundação Agrisus; FEALQ; Campinas: Instituto Agronômico.

EMBRAPA. 2006. Manual de métodos de análise de solo. 2. ed. Rio de Janeiro: Centro Nacional de Pesquisas de Solos, 2006. 212p.

Godoy, W. I; Silveira, E. R; Pagliosa, E; Trogello, E; Signorini, A; Cordeiro, Maikon; Pluciniski Filho, L. C. 2007. Analise da macrofauna do solo em dois sistemas de manejo: orgânico e convencional. Revista Brasileira de Agoecologia, Paraná, v.2, n.2, p.1273-1276.

Isaaks, E.H.; Srivastava, R.M. 1989. An introduction to applied geoestatistics. New York: Oxford University Press, 561p.

Lavelle, P. 1996. Diversity of soil fauna and ecosystem function. Biol. Intern., v.33, p.3-16.

Lourente, E. R. P; Silva, R. F; Silva, D. A; Marchetti, M. E; Mercante, F. M. 2007. Macrofauna edpafica e sua inteiração com atributos químicos e físicos do solo sob diferentes sistemas de manejo. Acta Sci. Agron. Maringá, v.29, n.1, p.17-22.

Magurran, A. E. 1989. Ecological Diversity and its measurement. Espanha: Vedra, 1989. p.200.

Melo, F. V.; Brown, G. G.; Constantino, R.; Louzada, J. N. C.; Luizão, F. J.; Morais, J. W.; Zanetti, R. 2009. A importância da meso e macrofauna do solo na fertilidade e como bioindicadores. Boletim Informativo da SBCS. p.38-43.

Merlim, A. O. 2005. Macrofauna edáfica em ecossistemas preservados e degradados de araucária no Parque Estadual de Campos de Jordão. 2005. 85p. (Mestrado em Ecologia de Agroecossistemas) - Universidade de São Paulo, São Paulo.

Oliveira, F.H.T.; Novais, R.F.; Alvarez V., V.H.; Cantarutti, R.B.; Barros, N.F. 2002. Fertilidade do solo no sistema plantio direto. Tópicos em Ciência do Solo, Viçosa, v. 2, p.393-486.

Oliveira, J.B. 2008. Pedologia Aplicada. 3o ed. Piracicaba: FEALQ, 592p.

Ortolani, A. A.; Camargo, M. B. P.; Pedro Jünior, M. J. 1995. Normais climatológicas dos postos meteorológicos do instituto agronômico: Centro Experimental de Campinas. Campinas. Instituto Agronômico, $13 p$.

Podgaiski, L. R.; Ott, R.; Ganade, G. 2007. Ocupação de microhabitats artificiais por invertebrados de solo em um fragmento florestal no sul do Brasil. Neotropical Biology and Conservacion, v.2, n.2, p. 71-79.

Primavesi, A. 1999. Manejo ecológico do solo: a agricultura em regiões tropicais. São Paulo: Nobel, 549p.

Rodrigues, K. M. 2010. Variabilidade espacial de atributos químicos, físicos e biológicos em voçoroca revegetada no município de Pinheiral, RJ. 2010. 60p. (Mestrado em Agronomia) - Universidade Federal Rural do Rio de Janeiro, Soropédica.

Rodrigues, W. C. 2007. DivEs - Diversidade de Espécies - Guia do Usuário. Seropédica: Entomologistas do Brasil. 2007. 9p. Disponível em: http://www.ebras.bio.br/dives/.

Schaefer, C. E. G. R.; Barros, N. F.; Mello, J. W. V.; Costa, J. M. 2000. Tópicos em Ciência do 
solo. Viçosa: Sociedade Brasileira de Ciência do Solo, v.2, p.1-45.

Schaffrath, V. R., Tormena, C. A., Gonçalves, A. C. A., Oliveira Junior, R. S. 2007. Variabilidade espacial de plantas daninhas em dois sistemas de manejo de solo. Revista Brasileira de Engenharia Agrícola e Ambiental, v.11, p. 53-60.

Seixas, F. 2000. Compactação do solo devido à colheita de madeira. Tese (Livre Docência) Escola Superior de Agricultura "Luiz de Queiroz", Universidade de São Paulo, Piracicaba.

Siqueira, G. M. 2006. Variabilidade de atributos físicos do solo determinados por métodos diversos. 2006. 163p. (Mestrado em Agricultura Tropical e Subtropical) - Instituto Agronômico de Campinas, Campinas.

Swift, M. J.; Heal, O. W.; Anderson, J. M. 1979. Decomposition in terrestrial ecosystems. Berkeley: University of California Press, p. 66117.

Vieira, S. R.; Hatfield, J. L.; Nielsen, D. R. \& Biggar, J. W. 1983. Geoestatitical theory and application to variability of some agronomical properties. Hilgardia, Berkeley, v.51 n.3, p.175.

Vieira, S.R. 2000. Geoestatística em estudos de variabilidade espacial do solo. In: Novais, R.F., Alvarez, V.H., Schaefer, G.R. (ed.) Tópicos em Ciência do solo. Viçosa: Sociedade Brasileira de Ciência do solo, v.1, 2000. p.154.

Vieira, S.R., Lombardi Neto, F., Burrows, I.T. 1991. Mapeamento da chuva máxima provável para o Estado de São Paulo. Rev.Bras. Cienc. Solo, 15, 93-98.

Vieira, S.R.; Millete, J.; Topp, G.C. \& Reynolds, W.D. 2002. Handbook for geoestatistical analysis of variability in soil and climate data. In: Alvarez, V.V.H.; (ed.) Tópicos em Ciência do solo. Viçosa: Sociedade Brasileira de Ciência do solo, v.1.

Warrick, A. W.; Nielsen, D.R. 1980. Spatial variability of soil physical properties in the field. In: HILLEL, D. Applications of soil physics. New York: Academic Press. 